
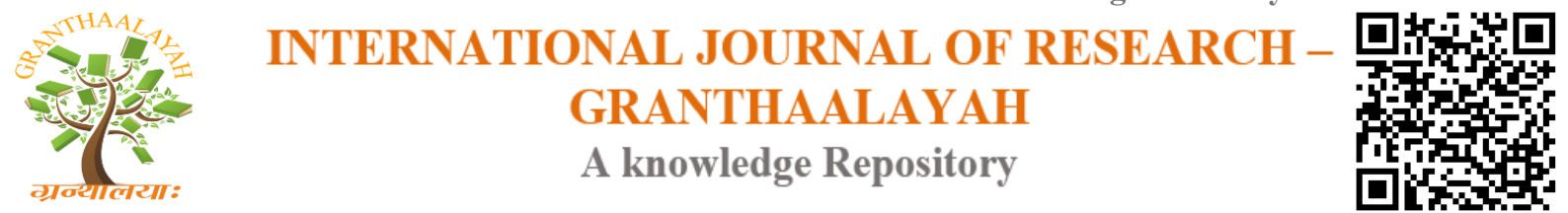

Social

\title{
ADJECTIVES IN TAMIL AND URDU - A COMPARATIVE STUDY
}

\author{
Dr. A. Mubarak Ali ${ }^{* 1}$ \\ ${ }^{* 1}$ Annamalai University, INDIA
}

\begin{abstract}
The aim of the paper is to compare the adjectives of Tamil Language which is one of the languages of Dravidian family and Urdu which is one of the members of Indo-Aryan family and bring out similarities and differences in their formation and usage in these two languages.
\end{abstract}

Keywords:

Adjectives, Simple adjectives, Derived Adjectives, adjectivalizer, Universal and specific.

Cite This Article: Dr. A. Mubarak Ali, "ADJECTIVES IN TAMIL AND URDU - A COMPARATIVE STUDY” International Journal of Research - Granthaalayah, Vol. 4, No. 5: SE (2016): 67-71.

\section{INTRODUCTION}

Though the adjectives are universal to world languages, they differ in their function and occurrences. In some world languages the adjectives have to agree with the noun in respect of gender, number and definiteness and in respect of case endings and in other this is not the situation. In some world languages the adjectives are placed before the noun languages and the other placed after the noun and also the adjective is used with intensifier. Eventually this paper attempts to explain about the types and formation of adjectives in Tamil and Urdu Languages.

\section{ADJECTIVES}

Adjectives are words that describe or give information about nouns or pronouns. They are therefore often said to modify, or limit, nouns and pronouns. Adjectives are usually easy to recognize in a sentence, often describing or modifying an object's size colour or amount. (Pahuja.N.P:p5)

A word used with noun to describe or point out, the person, animal, place or thing which the noun names, or to tell the number or quantity, is called an Adjective. So we may define an Adjective as a word used with a noun to add something for its meaning (Wren \& Marti:p-19)

\begin{tabular}{|l|l|l|}
\hline & Tamil & Urdu \\
\hline Person & nalla paiyan & acchaa ladkaa \\
\hline
\end{tabular}




\begin{tabular}{|l|l|l|}
\hline & Good boy & Good boy \\
& Nalla peN & Acchi ladki \\
& Good girl & Good girl \\
\hline Animal & Karuppu aaTu & kaalibakri \\
& Black goat & Black goat \\
& Uyarmaana aaTu & Unci bakri \\
& Tall goat & Tall goat \\
\hline Place & Periya kaTTiTam & badaa imaarat \\
& Big building & Big building \\
& Ciriya kaTTiTam & Chota imaarat \\
& Small building & Small building \\
\hline
\end{tabular}

On the basis of their structure, the adjectives may be grouped into simple adjective and derived adjective.

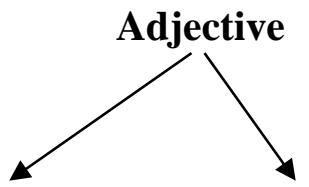

Inherent or Simple adjective Derived adjective

\section{SIMPLE ADJECTIVES}

Those words which have adjectival function and which are not descriptively derived from any other grammatical derived from any other grammatical category are called simple adjective

\begin{tabular}{|l|l|l|}
\hline Tamil & Urdu & Meaning \\
\hline $\begin{array}{l}\text { Nalla } \\
\text { keTTa }\end{array}$ & $\begin{array}{l}\text { achchaa } \\
\text { qaraab }\end{array}$ & $\begin{array}{l}\text { Good } \\
\text { bad }\end{array}$ \\
\hline $\begin{array}{l}\text { Periya } \\
\text { ciriya }\end{array}$ & $\begin{array}{l}\text { badaa } \\
\text { choota }\end{array}$ & $\begin{array}{l}\text { Big } \\
\text { small }\end{array}$ \\
\hline iniya & MiiTha & sweet \\
\hline
\end{tabular}

\section{DERIVED ADJECTIVES}

Givon (1970:816) remarked of English that "of all adjectives in the dictionary, only a small number are original or overtly underived; the great bulk are morphologically derived from either nouns or verbs, but there appear to be more derivations forming adjectives than for the other word classes. (Asher.R.E:p30)

Those words which have adjectival function and which are derived from nouns are called derived adjectives.

\begin{tabular}{|l|l|l|}
\hline Tamil & Urdu & Meaning \\
\hline Naankaavatu paTi & Chaarvisidi & fourth step \\
\hline ALakaana pen & Khubsuurat ladki & beautiful girl \\
\hline Viramulla paiyan & Baahadur ladkaa & bravest boy \\
\hline
\end{tabular}




\begin{tabular}{|l|l|l|}
\hline arivuTaiya paiyan & Aql waalaa ladkaa & brilliant boy \\
\hline
\end{tabular}

\section{COMPARATIVE STUDY}

Both in Tamil and Urdu, the adjectives are placed immediately before the noun. In Urdu, the simple adjectives are of two types, the first type adjectives shows agreement with the nouns according to gender and number which are qualified by adjectives as

$$
\begin{aligned}
& \text { kaalaa kapdaa (mas.sing) } \\
& \text { Black cloth } \\
& \text { kaali saadi (fem.sing) } \\
& \text { Black saree } \\
& \text { uncaa ladkaa } \\
& \text { tall boy } \\
& \text { unci ladki } \\
& \text { tall girl }
\end{aligned}
$$

and the second type does not show any change as

$$
\begin{array}{cc} 
& \begin{array}{l}
\text { laal kapdaa } \\
\text { Red cloth } \\
\text { laal saadi, }
\end{array} \\
\text { Red saree } & \\
& \\
\text { Qaraab ladkaa } \\
\text { Bad boy } \\
\text { Qarab ladki } \\
\text { Bad girl }
\end{array}
$$

This situation does not prevail in Tamil

$$
\begin{aligned}
& \text { Karupput tuNi (neu.sing) } \\
& \text { Black cloth } \\
& \text { karuppup puTavai (neu.sing). } \\
& \text { Black saree } \\
& \text { keTTa paiyan } \\
& \text { bad boy } \\
& \text { keTTa peN } \\
& \text { bad girl } \\
& \text { uyarmaana paiyan } \\
& \text { tall boy }
\end{aligned}
$$




$$
\begin{aligned}
& \text { uyarmaana peN } \\
& \text { tall girl }
\end{aligned}
$$

For plural, the simple adjectives of Urdu show change according to number and gender as

$$
\begin{aligned}
& \text { kaale kapde (mas.pl.) } \\
& \text { Black cloth } \\
& \text { kaali sadiyan } \\
& \text { Black sarees }
\end{aligned}
$$

But in Tamil this change is absent as

$$
\text { karupput tuNikaL (neu.pl.) }
$$

Black cloth

karuppup puTavaikaL

Black sarees

The derived adjectives in Urdu are formed with the adjectivalizer "waalaa", " kaa" "vi" and in Tamil with "aana", "uLLa" and "uTaiya" "aavatu"

\begin{tabular}{|l|l|}
\hline Urdu & Tamil \\
\hline $\begin{array}{l}\text { gusse waalaa aadmi } \\
\text { The man with angry }\end{array}$ & kopamaana manitan \\
The man with angry \\
The man with affection \\
kapdeekaa pardaa & $\begin{array}{l}\text { anpaana manitan } \\
\text { The man with love }\end{array}$ \\
Cloth curtain & poruppuLLa manitan \\
jhaadkaa palang & The man with responsibility \\
wooden cot & PoruppuTaiya patavi \\
chaarvi sidi & Responsible post \\
fourth step & Naankavatu paTi \\
\hline
\end{tabular}

\section{CONCLUSION}

In Urdu the simple adjectives are two types and in Tamil only one. The derived adjectives in Urdu are formed with the markers "waalaa" "kaa" "vi"and in Tamil with "aavatu" "aana", "uLLa", "uTaya". In Urdu, the adjectives both simple and derived agree with the noun according to gender and number but the Tamil adjectives do not change. In Tamil and Urdu both simple and derived adjectives take a degree modifier as

Bahut acchaa ladkaa

Very good boy migavum nalla paiyan

very good boy 
This situation shows that the formation and function of adjectives are specific to languages of the world.

\section{REFRENCES}

[1] Andronov.M, 1969, A Standard Grammar of modern and classic Tamil, New century Book house pvt.Ltd., Madras.

[2] David Crystal 1985, A Dictionary of Linguistics and phonetics, Basil Blackwell Ltd, U.K.

[3] Asher. R.E., 1994, The encyclopedia of language and linguistics,Pergaonon Press Ltd., England.

[4] Khawaja Muhammad Zakaria, 1995 Learn Urdu in Two months, Classic Arts, New Delhi.

[5] Pon.Kothandaraman 1997, A Grammer of Contemporary Literature Tamil, International Institute of Tamil Studies, Chennai

[6] Pahuja.N.P. 1997, Dictionary of grammar, Anmol Publications Pvt. Ltd., New Delhi.

[7] Renugadevi.S.1997, Grammatical Comparison of Tamil and English: A typological study, Devi publications, Madurai.

[8] Wren \& Martin, 2000, High school English grammer and composition, S.Chand and company Ltd, New Delhi.

[9] Ravindergarges \& Chander Shekar, 2001, Introductory Grammer of Urdu, Ncpul, New Delhi.

[10] Aziz-ur-Rahman,2001, Teach yourself Urdu, Islamic book service, New Delhi. 